\title{
Activity Based Costing, Time-Driven Activity Based Costing and Lean Accounting: Differences among three accounting systems' approach to manufacturing
}

\author{
Carlos Rodriguez Monroy ${ }^{1}$, Azadeh Nasiri, Miguel Ángel Peláez
}

\begin{abstract}
Choosing an appropriate accounting system for manufacturing has always been a challenge for managers. In this article we try to compare three accounting systems designed since 1980 to address problems of traditional accounting system. In the first place we are going to present a short overview on background and definition of three accounting systems: Activity Based costing, Time-Driven Activity Based Costing and Lean Accounting. Comparisons are made based on the three basic roles of information generated by accounting systems: financial reporting, decision making, and operational control and improvement. The analysis in this paper reveals how decisions are made over the value stream in the companies using Lean Accounting while decisions under the $\mathrm{ABC}$ Accounting system are taken at individual product level, and finally we will show how TD-ABC covers both product and process levels for decision making. In addition, this paper shows the importance of nonfinancial measures for operational control and improvement under the Lean Accounting and TD-ABC methods whereas $\mathrm{ABC}$ relies mostly on financial measures in this context.
\end{abstract}

Keywords: Accounting, Activity Based Costing, Time-Driven Activity Based Costing, Lean Accounting, Manufacturing

\footnotetext{
${ }^{1}$ Carlos Rodríguez Monroy $(\square)$

Departamento de Ingeniería de Organización, Administración de Empresas y Estadística. Escuela Técnica Superior de Ingenieros Industriales, Universidad Politécnica de Madrid

e-mail: cmonroy@etsii.upm.es
} 


\subsection{Introduction}

In the past, before 1980, accounting systems had a completely different approach. Those systems could not support management, planning and decision making (Johnson and Kaplan, 1987). Such accounting systems were not fit for recent everchanging market and competitive environment any more.

At that time, in order to deal with new challenges some companies approached Activity Based Costing introduced by Cooper and Kaplan in 1987 and some others applied the lean manufacturing concept founded on the constant elimination of waste. Lean accounting, based on lean thinking refers to efforts to develop financial management based on lean principles. In 2004, Kaplan "father of Activity Based Costing" reviewed his method and accepted the criticism that ABC requires too much work and that it is difficult for a company to maintain it over time. Therefore, Kaplan introduced Time-Driven $\mathrm{ABC}$ as a new solution, referring to problems recognized in the ABC method. On the other hand, in 2005, leaders in Lean Accounting reached an agreement on a document called "The Principles, Practices, and Tools of Lean Accounting" in order to develop a single and clear definition for Lean Accounting.

\subsection{Literature}

\subsubsection{Activity Based Costing (ABC)}

The ABC method actually was the reply to inaccurate American accounting standards (Kuchta and Troska 2007). ABC Methods were concerned with what was done in terms of activities instead of what was spent. A number of cost pools and a variety of cost drivers are the key differences of $\mathrm{ABC}$ and traditional costing (Don and Shannon, 2007). Actually the activity cost pool is the overall cost associated with an activity. In addition, the cost driver, which justifies changing the costs in an activity cost pool over time, is a feature that affects the cost and performance of the activity (Kennedy, 1996). It is assigning indirect costs first on activities and then on cost objectives (product, service or costumer) what makes requests for these indirect costs (Cooper and Kaplan, 1988b). The expenses of indirect resources are allocated to the different activities via resource drivers. Besides, activity drivers represent the consumption of activities by the different cost objects (Bruggeman and Hoozee, 2010). It can be said that ABC models the causal relationships between products and the resources used in their production and traces the cost of products according to the activities through the use of appropriate cost drivers (Bogdanoiu, 2009). The following stages can be concluded for Activity Based Costing: 1. Identifying activities, 2. Defining the 
cost of the activities, 3. Defining the cost drivers of the activities, 4. Defining the volume of cost drivers, 5. Defining unit cost per cost driver for each activity and 6. Calculating the unit cost per product or service (Cooper and Kaplan, 1998), (Bruggeman and Everaert, 2007), (Krumweide, 1998)

\subsubsection{Time-Driven Activity Based Costing (TD-ABC)}

This method identifies the capacity of each department or process and allocates the cost of this capacity of resource groups over the cost object based on the time required to perform an activity. If the demand for work in these departments or processes declines, TD ABC can estimate the quantity of resources released (Kaplan, 2006).TD-ABC captures the different characteristic of an activity by time equations in which the time consumed by an activity is a function of different characteristics. This equation assigns the time and the cost of the activity to the cost object based on characteristics of each object. The unit cost of used resources and time required to perform an activity are two parameters for this method. The time-driven approach consists of six steps (Bruggeman and Everaert, 2007):1.Identifying resource groups and the activities for which they are used, 2. Defining the costs of each group, 3. Estimating the practical capacity of each group, 4. Calculating cost per time unit, 5 . Determining the required time units for each activity, 6. Calculating cost per transaction.

\subsubsection{Lean Accounting (LA)}

The lean concept is a philosophy that non-value-adding activities are being recognized and eliminated in lean manufacturing systems. It contains a set of principles and practices aimed to reduce cost over removal of waste and done with simplification of all manufacturing processes (Blackstone et al., 2005). Then not only non-value-adding activities in accounting processes as well as other processes have to be removed but also the accounting system itself should interpret the results of efforts in lean manufacturing. Lean Accounting methods and tools support three key aspects of a lean organization: visual management, value stream management, and continuous improvement (Kennedy and Maskell, 2007).

A set of tools are used to support the five principles of Lean Accounting. A short review of the Lean Accounting framework including principles, practices and tools has been described as follows:

The first principle is "Lean \& simple business accounting". This principle is applying lean method to the accounting processes using lean tools such as value stream maps, kaizen and the Plan-Do-Check-Act (PDCA) problem-solving approach. The second principle refers to accounting processes that support the Lean 
Transformation. Control of production processes is doing by visual performance measurement tools and box score and also value stream performance board supports continues improvement. Value stream costing tools motivates lean improvement across the entire value stream and target costing is another tool that guarantees customer satisfaction. "Clear\& timely communication of information" is the third principle of Lean Accounting. Visual management is supported by visual performance boards attached to box score tools. Box score presents the operational performance and the financial performance in one sheet. This tool is also widely used for decision making purposes. Plain English income statement without including unclear data regarding standard costs is another tool supporting this principle. "Planning from a lean perspective" is another principle in Lean accounting. Hoshin policy deployment, Sales, Operations \& Financial Planning (SOFP), value stream cost and capacity analysis, value stream maps and box scores are tools that support this principle as well. Finally, Lean Accounting must strengthen internal accounting control. This principle is supported by the Transaction Elimination Matrix which is a tool to ensure that Lean Accounting changes are made wisely. Also, process maps showing controls and Sarbanes Oxley regulations (SOX) are used in improvement projects to decrease the SOX risks (Maskell and Baggaley, 2006).

\subsection{Discussion}

Here we will discuss the differences among these different accounting methods based on the three basic roles of accounting information in organizations: Financial reporting, decision making and planning and operational control and improvement (Cooper and Kaplan, 1998).

\subsubsection{Financial reporting:}

Financial reporting which is one of the basic purposes of an accounting system has to follow Generally Accepted Accounting Principles (GAAP). Reports produced by $\mathrm{ABC}$ and $\mathrm{TD}-\mathrm{ABC}$ are not adapted to GAAP and companies that are using these systems should have another system generating reports for external uses. Meanwhile, financial reports of Lean Accounting comply totally with GAAP. External reporting regulates internal reporting requirements (Baggaley and Maskell, 2006).

\subsubsection{Decision making and planning}


The firms which were candidates for the first practice of the ABC system had several individual product lines and large numbers of products were produced in those lines. Products were served to different marketing channels. High volume and low volume products had a wide range of demand. The greater range of demand, the greater the variation of lot sizes of products for manufacturing and shipping (Cooper and Kaplan, 1988a). This caused a complex management environment and complexity required more costs to be managed. Based on the $\mathrm{ABC}$ model overhead is not just a certain cost that has to be allocated regardless of the complexity involved. All costs of performing an activity are correspondingly allocated to cost objects based on the activity cost driver. Consequently a more realistic view of products was provided to support decision making. ABC systems enabled managers to recognize marginal, low-volume, complex products and any other elements that could charge the companies with additional cost on products. Under this recognition they could make the decision to stop producing these types of products. Companies began to regulate their decisions and strategy according to what they had learned from ABC. They recognized that they are more competitive on high-volume and low complex products than they had thought before. There are many other management decisions made on the basis of information gained from ABC. For example, "If batch costs such as setups, orders, or shipments were high, they would try to negotiate with their customers to reduce frequency of these activities or obtain payment to make up for the cost"(Grasso, 2005). The new and accurate information on each product and costumer cost enables companies to remove products involving extra activities that cause supplementary costs if their price did not cover the additional costs required by these activities. All the abovementioned examples indicate that decision making takes place at the product level.

Lean Accounting based on lean thinking relies on management of the overall system. In other words: it collects costs and provides accounting information over the value stream, which is defined as all the activities for taking products or services from conception to the costumer. Total cost of all labour, machinery and facilities, materials and support services is counted within the value stream. Cost data is typically collected weekly and there is little or no allocation of overheads (Baggaley and Maskell, 2006). Financial information, such as profit and loss reports are gathered focused on value stream profitability. "The value stream income statement serves as the primary tool in providing monetary information for decision making and reflects revenues from which direct material and all workers, machine and other conversion costs are deducted to obtain value stream profit" (Moreland, and Thomson, 2007). Also, routine decision-making such as: make or buy, sourcing a new product, product justification, profitability, or any other, is reached by means of tools, such as Box Score, which use incremental costs for the decisions and takes advantage of the free capacity calculated on the value stream. All the above-mentioned situations emphasize that in the Lean Accounting system, although product cost might be calculated in some special cases, generally the foundation for decision making are value stream costing and Box Score which collect the required information over the value stream. 
A Time-Driven ABC model identifies the capacity of each department or process and assigns the cost of this capacity on the required work done in the process. This is similar to the cost collection in the value stream in Lean Accounting. Besides that, throughout the process or product, the used and unused capacity of processes are being calculated, which is comparable to "productive capacity", "non-productive capacity" and the "available capacity" presented on the box score in Lean Accounting. Therefore, if the demands for work in these departments decrease because of process optimization or any other reasons, the capacities of resources released are being estimated. Therefore managers would be able to manage the free resources in the flow (Kaplan, 2006). Or in any other cases such as new market development, new product introductions or rising product and customer demands that managers might be involved with capacity shortage, they come to decisions on how much they will require handling increasing demands. All these examples illustrate that decision making in TD ABC takes place on both production and process level whereas traditional $\mathrm{ABC}$ is based on actual utilization and does not identify the vacant capacity.

\subsubsection{Operational control and improvement}

In the $\mathrm{ABC}$ method Kaplan and Cooper recognize the importance of nonfinancial measures, particularly quality and time-related measures, but they maintain that financial measures must still play an important role. ABC provides a means for prioritizing improvement efforts and for assessing the performance efficiency of activities. Cooper and Kaplan also cite cases where financial measures provide powerful motivation for improvement (Cooper and Kaplan, 1998).

Instead of cost data, which is usually not easy to report in real time, cost management in lean accounting method relies on direct quality, quantity and time information of activity or process in order to control the cost, since the emphasis on cost management is on efforts associated with cost planning and monitoring rather than cost control. Therefore cost planning exceeds cost control in this method. One of the other important elements of the process of cost management is continuous improvement of processes and in order to do so, critical parameters of processes must be monitored nonstop (Kilger et al., 2004). In lean manufacturing the processes are controlled by visual performance measurement in the value stream. Charts and graphs for the main measures of process performance showing trend lines in actual performance are announced on boards in the production line. These key performance measures in lean systems are considered as a replacement for variance financial reporting generated from traditional cost accounting which motivated continuous improvement in the past. In this method financial results are passengers not drivers (Grasso, 2005). In order to support continuous improvement Lean Accounting also uses the value stream performance board which is a visual board including continuous improvement projects. PDCA projects are being 
initiated and the progress of these projects is being monitored. Finally "Lean Accounting motivates long-term lean improvement through lean focused information and measurements. Lean performance measurements are cornerstones of control in the value stream, and in the overall plant or company" (Baggely and Maskell, 2006).

The practical capacity is a key element in the TD-ABC method because inevitable and unused capacity in conventional $\mathrm{ABC}$ overestimates product and costumer costs. The Time-Driven ABC approach was an attempt to avoid this distortion. After identifying practical capacity for resource groups, the other key element in $\mathrm{TD} \mathrm{ABC}$ is unit time for activities performed by this group, so cost generation in TD ABC is based on time consumption and unit time has to be calculated. Usually the unit time is being used by manager for strategic visions and for this purpose a rough estimate is enough, but the point is that gross inaccuracy in unite time will be ended to unexpected surpluses or shortages of committed resources (Anderson and Kaplan, 2004). It is obvious that unit time can be the centre of attention for improvements. Analysts now need to monitor closely the resource requirements, quality and cycle times of activities and processes to motivate and capture improvements. Moreover, TD ABS accounting can be applied using only unit cost and unit time, and time consumption is the only cause that generates cost in the TD-ABC accounting method. Both of them somehow are representing the efficiency of business processes. Therefore companies can focus on high cost and inefficient processes for improvement efforts. According to all the abovementioned reasons it seems that cost is not a driver for improvement and TD-ABC does not emphasize financial measures as a driver for improvement.

\subsection{Conclusions}

In this paper we have analysed, $\mathrm{ABC}$, Time-Driven $\mathrm{ABC}$ and Lean Accounting with respect to three main roles of information generated by accounting systems. The result of this analysis has been summarized in Table 1.1.

Table 1.1 Different approachesfor information generated from each accounting system based on financial reporting, decision making and operational control and improvement

\begin{tabular}{|l|l|l|l|}
\hline & \multicolumn{1}{|c|}{$\begin{array}{c}\text { Activity Based } \\
\text { Costing }\end{array}$} & $\begin{array}{c}\text { Time-Driven Ac- } \\
\text { tivity Based Costing }\end{array}$ & \multicolumn{1}{|c|}{ Lean Accounting } \\
\hline $\begin{array}{l}\text { Financial report- } \\
\text { ing }\end{array}$ & $\begin{array}{l}\text { Not accepted by } \\
\text { GAAP }\end{array}$ & $\begin{array}{l}\text { Not accepted by } \\
\text { GAAP }\end{array}$ & Accepted by GAAP \\
\hline Decision making & $\begin{array}{l}\text { Takes place at prod- } \\
\text { uct level }\end{array}$ & $\begin{array}{l}\text { Takes place at product } \\
\text { and process level }\end{array}$ & $\begin{array}{l}\text { Takes place at value } \\
\text { stream level }\end{array}$ \\
\hline $\begin{array}{l}\text { Operational con- } \\
\text { trol and im- } \\
\text { provement }\end{array}$ & $\begin{array}{l}\text { Emphasis on } \\
\text { financial measures }\end{array}$ & $\begin{array}{l}\text { Emphasize on non- } \\
\text { financial measures }\end{array}$ & $\begin{array}{l}\text { Emphasize on non- } \\
\text { financial measures }\end{array}$ \\
\hline
\end{tabular}




\subsection{References}

Anderson, S.R. and Kaplan, R.S. (2004) Time-Driven Activity-Based Costing, Harvard Business Review, Vol. 82, pp. $131-138$.

Baggaley, B. L. and Maskell, B. H. (2006) Lean Accounting: What's It All About?, Target magazine, Vol 22 (No1).

Blackstone, Cox, J. H. and Cox, J. F. (2005) APICS Dictionary (11th edition), APICS, Alexandria, VA.

Bogdanoiu, C. (2009) Activity Based Costing from the perspective of competitive advantage, Journal of Applied Economic Sciences, 1 (7): 5 - 11.

Bruggeman W.,Everaert P. (2007) Time-driven Activity-based Costing: exploring the Underlying Model, Cost Management, 21(2), pp. 16-20.

Bruggeman, W.,Hoozee, S. (2010) Identifying operational improvements during the design process of a time-driven $\mathrm{ABC}$ system: the role of collective worker participation and leadership style, Management Accounting Research 21 (3), 185-198.

Don, H.and Shannon, L.C (2008) An evaluation of activity-based costing and functional-based costing: A game-theoretic approach, International Journal of Production Economics, Volume: 113, Issue: 1, Pages: 282-296.

Cooper, R. and Kaplan, R.S. (1988a) How Cost Accounting Distorts Product Costs, Management Accounting.

Cooper, R. and Kaplan, R.S. (1988b) Measure costs right: make the right decisions, Harvard Business Review, pp. 96-103.

Cooper, R. and Kaplan, R.S. (1998) Cost and Effect, Harvard Business School Press, Boston.

Grasso, L. (2005) Are ABC and RCA Accounting Systems Compatible with Lean Management? Management Accounting Quarterly, Vol 7(No1).

Johnson, H. T. and Kaplan, R. S. (1987) Relevance Lost: The Rise and Fall of Management Accounting, Harvard Business School Press, Boston.

Kaplan, R.S. (2006) The competitive advantage of management accounting, Journal of management accounting research, Vol18.

Kennedy, A. (1996) ABC basics (activity-based costing), journal of Management Accounting (British)

Kennedy F.A. and Maskell. B.H. (2007) Why do we need lean accounting and how does it work? Journal of Corporate Accounting \& Finance, Volume 18, Issue 3, pages 59-73.

Kilger, W., Pampel, J. and Vikas, K. (2004), Introduction: Marginal Costing as a Management Tool, Management Accounting Quarterly, pp. 7-28.

Krumweide K.R. (1998) The Implementation Stages of ABC and the Impact of Contextual and Organizational Factors, Journal of Management Accounting Research, No. 10, pp. 239-278.

Kuchta, D. andTroska, M. (2007) Activity Based Costing and Customer Profitability. Cost Management, 21 (3): $18-25$.

Moreland, A.V. and Thomson, J. (2007) The Lowdown on Lean Accounting, Journal of strategic finance, P. 26-55 